OPEN ACCESS

Edited by:

Robert Lindsay Medcalf, Monash University, Australia

Reviewed by:

Vince Ellis,

University of East Anglia, UK Andre Laval Samson,

The Heart Research Institute, Australia

*Correspondence:

Denis Vivien

vivien@cyceron.fr

tThese authors have contributed equally to this work.

Received: 19 June 2015 Accepted: 01 October 2015 Published: 16 October 2015

Citation: Chevilley A, Lesept F, Lenoir S, Ali C, Parcq $J$ and Vivien D (2015) Impacts of tissue-type plasminogen activator

(tPA) on neuronal survival.

Front. Cell. Neurosci. 9:415. doi: 10.3389/fncel.2015.00415

\section{Impacts of tissue-type plasminogen activator (tPA) on neuronal survival}

\author{
Arnaud Chevilley, Flavie Lesept ${ }^{\dagger}$, Sophie Lenoirt', Carine Ali, Jérôme Parcq and \\ Denis Vivien*
}

INSERM, UMR-S U919 Serine Proteases and Pathophysiology of the Neurovascular Unit, Université Caen-Normandie, Caen, France

Tissue-type plasminogen activator (tPA) a serine protease is constituted of five functional domains through which it interacts with different substrates, binding proteins, and receptors. In the last years, great interest has been given to the clinical relevance of targeting tPA in different diseases of the central nervous system, in particular stroke. Among its reported functions in the central nervous system, tPA displays both neurotrophic and neurotoxic effects. How can the protease mediate such opposite functions remain unclear but several hypotheses have been proposed. These include an influence of the degree of maturity and/or the type of neurons, of the level of tPA, of its origin (endogenous or exogenous) or of its form (single chain tPA versus two chain tPA). In this review, we will provide a synthetic snapshot of our current knowledge regarding the natural history of tPA and discuss how it sustains its pleiotropic functions with focus on excitotoxic/ischemic neuronal death and neuronal survival.

Keywords: tissue-type plasminogen activator, excitotoxicity, apoptosis, NMDA receptors, differential effects

\section{THE NATURAL HISTORY OF tPA}

Morgagni (1761) noted that the blood of patients who died suddenly was not completely coagulated. Denis (1838) observed the spontaneous dissolution of blood clots. Fifty years later, Denys and de Marbaix (1889) postulated the existence of an endogenous fibrinolytic enzyme. Accordingly, Hedin (1903) revealed a proteolytic activity in serum globulin fraction, later identified as the fraction containing a precursor of plasmin. Christensen and Macleod (1945) proposed that this inactive circulating precursor, named plasminogen, could be activated by bacterial extracts like streptokinase. Macfarlane and Biggs (1948) completed the description of the plasminogen activation cascade. In parallel, Conradi (1902) identified tPA, at this time named fibrikinase, in different organs), later characterized to mediate fibrinolysis (Fleisher and Loeb, 1915; Astrup and Permin, 1947; Astrup and Stage, 1952). tPA was then purified from human vessels and uterus in Binder et al. (1979), Rijken et al. (1979) and in larger amounts from Bowes melanoma cell line allowing its biochemical characterization (Collen et al., 1982; Collen and Lijnen, 2009). Pennica et al. (1983) succeeded in cloning and expressing recombinant tPA, providing the primary structure of tPA. tPA is a protein of 527 amino-acids including three glycosylation sites and 17 disulfide bridges (Pennica et al., 1983). Collen and Lijnen (1991) then provided evidence that tPA could facilitate the dissolution of blood clots by inducing the degradation of fibrin in a plasminogendependent manner. IPA is now used in the clinic to promote fibrinolysis, especially at the acute phase of ischemic stroke either alone (NINDS, 1995) or combined with thrombectomy (Campbell et al., 2015; Goyal et al., 2015). 
In addition to this fibrinolytic function at the origin of its discovery, an increasing number of studies have since the mid90s, discovered functions of tPA within the brain parenchyma. In particular, tPA is believed to control neuronal fate during several CNS disorders, including multiple sclerosis, Alzheimer's disease, and stroke. The aim of this review is to summarize and discuss structure-function studies related to the influence of tPA on neuronal death and survival.

\section{tPA OR tPAS?}

The mature form of tPA is a mosaic protein of five distinct modules, which, from its $\mathrm{N}$-terminal end to its C-terminal end, are: a finger domain (F), an epidermal growth factor-like domain (EGF), two kringle domains (K1 and $\mathrm{K} 2$ ), and a serine protease proteolytic domain (SP). The finger domain is involved in tPA binding to fibrin and is necessary to promote fibrinolytic activity at low plasminogen activator concentrations (Larsen et al., 1988). In the brain, other functions attributed to the finger domain include its ability to cross the blood-brain barrier (Benchenane et al., 2005), its astrocytic clearance (Cassé et al., 2012) and some of its signaling pathways (Siao and Tsirka, 2002; Pineda et al., 2012). The EGF-like domain shows homology with EGF. Both the trophic and mitogenic functions of tPA have been attributed to this domain (Liot et al., 2006; Ortiz-Zapater et al., 2007; Correa et al., 2011; Haile et al., 2012). The EGF-like domain has been also reported to contribute to the hepatic recapture of tPA (Hajjar and Reynolds, 1994). The kringle domains fold into large loops stabilized by three disulfide bridges. Because of the high-mannose-type glycosylation at Asn117, K1 is of major importance in the uptake of tPA by mannose receptors on liver endothelial cells in vivo and in vitro (Kuiper et al., 1996). The K2 domain and more specifically its lysine binding site (LBS) is involved in the capacity of tPA to bind and activate substrates and/or receptors such as plasminogen, PDGF-CC (platelet derived growth factor-CC; Fredriksson et al., 2004) and NMDAR ( $N$-methyl-D-aspartate receptor; López-Atalaya et al., 2008). The K1 of tPA does not possess a LBS (Kim et al., 2003). The C-terminal domain supports the catalytic activity of tPA and forms the catalytic triad (His 322, Asp 371, and Ser 478) involving an aspartic acid residue (Asp371) hydrogen-bonded to a histidine (His322), which itself is hydrogen-bonded to a serine (Ser478).

As detailed here after, the literature suggests that there is not one but several forms of tPAs.

\section{Long and Short Variants}

The pro-form of tPA is a molecule of 562 amino acids. The signal peptide and a pro-peptide of, respectively, 22 and 10 amino acids should be removed before storage in vesicles and release. Three additional amino acids (Gly-Ala-Arg) at the $\mathrm{N}$-terminal end of the molecule can be also removed leading to the release of either the long variant (L-tPA) or the short variant (S-tPA) of 530 and 527 amino acids, respectively (Jörnvall et al., 1983; Berg and Grinnell, 1991). These tPAs include 17 disulfide bridges.

\section{sc-tPA vs. tc-tPA}

In contrast to the other members of the chymotrypsin family, tPA is not synthesized and secreted as a "true" zymogen (Madison et al., 1993). Like other members of the family, the secreted single-chain tPA (sc-tPA; Figure 1A) can be processed into a two-chain form tPA (tc-tPA; Figure 1B) by plasmin or kallikrein (Wallén et al., 1982; Ichinose et al., 1984). However, sc-tPA is an unusually active zymogen (high intrinsic proteolytic activity, low zymogenicity) that does not require proteolytic processing to be active but relies on the presence of an allosteric regulator, such as fibrin (Thelwell and Longstaff, 2007). The passage from the sc-tPA to the tc-tPA form results from the hydrolysis of the peptide bond linking the Arg275 and the Ile276, both parts of the protein remaining connected by a disulfide bridge between Cys299 (heavy chain A) and Cys430

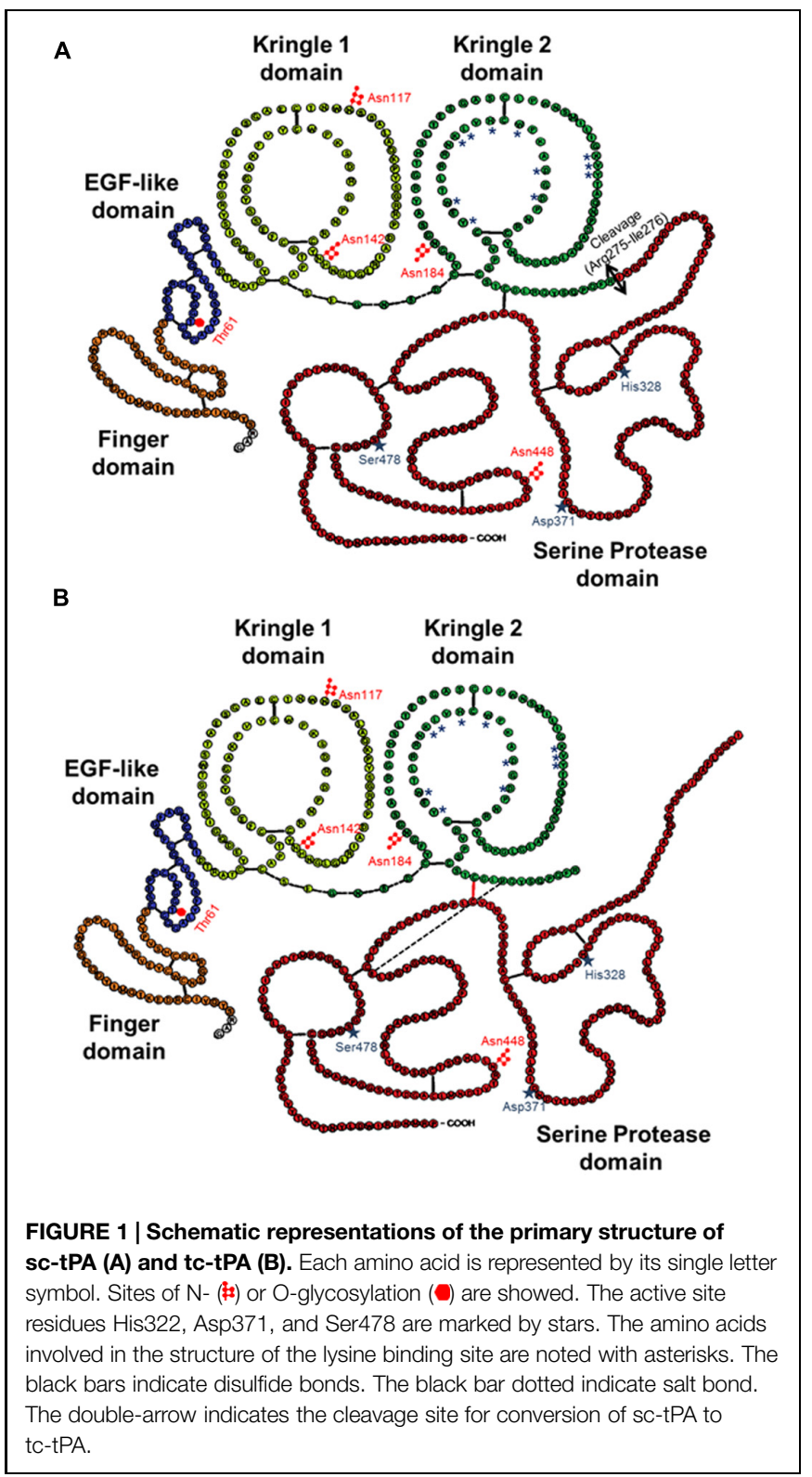


(light chain B) and a novel salt bridge between Arg302 and Glu445 (Lamba et al., 1996). In the absence of an allosteric regulator such as fibrin, tc-tPA is fivefold catalytically more active than sc-tPA (Rånby et al., 1982; Wallén et al., 1982; Tate et al., 1987; Petersen et al., 1988; Boose et al., 1989). However, in the presence of fibrin, both sc-tPA and tc-tPA display the same catalytic activity (Thelwell and Longstaff, 2007).

\section{Type I vs. Type II tPA}

Type plasminogen activator is a glycoprotein containing three major N-glycosylation sites. Two glycosylations are constitutives at Asn 117 within the kringle 1 domain and at Asn 448 within the serine protease domain. A third one is alternative at Asn184 within the kringle 2 domain. Type I tPA is glycosylated at Asn117, Asn184, and Asn448, while type II tPA is glycosylated only at Asn117 and Asn448 (Pohl et al., 1984; Spellman et al., 1989; Mori et al., 1995; Jaques et al., 1996). Asn184 acts as a switch that enables long-distance communication between fibrin-binding residues (achieved by the finger domain) and the catalytic site in the protease domain (Rathore et al., 2012). Glycosylation of Asn184 (i.e., type I) reduces the ability of tPA to activate plasminogen as well as its binding to fibrin (Einarsson et al., 1985; Wittwer et al., 1989; Berg et al., 1993). Type I sc-tPA seems to be more stable than type II sc-tPA regarding its conversion to tc-tPA (Wittwer and Howard, 1990; Berg et al., 1993; Figure 2). tPA also contains a O-linked fucose at Thr61 (occupancy 100\%) within the EGF domain (Harris et al., 1991) and potentially an additional N-glycosylation site at Asn142 within the K1 domain (occupancy 1\%; Borisov et al., 2009).

\section{IS TPA GOOD OR BAD FOR NEURONAL SURVIVAL?}

\section{The Facts}

The group of Sidney Strickland was the first to demonstrate that tPA deficient mice were more sensitive to hippocampal

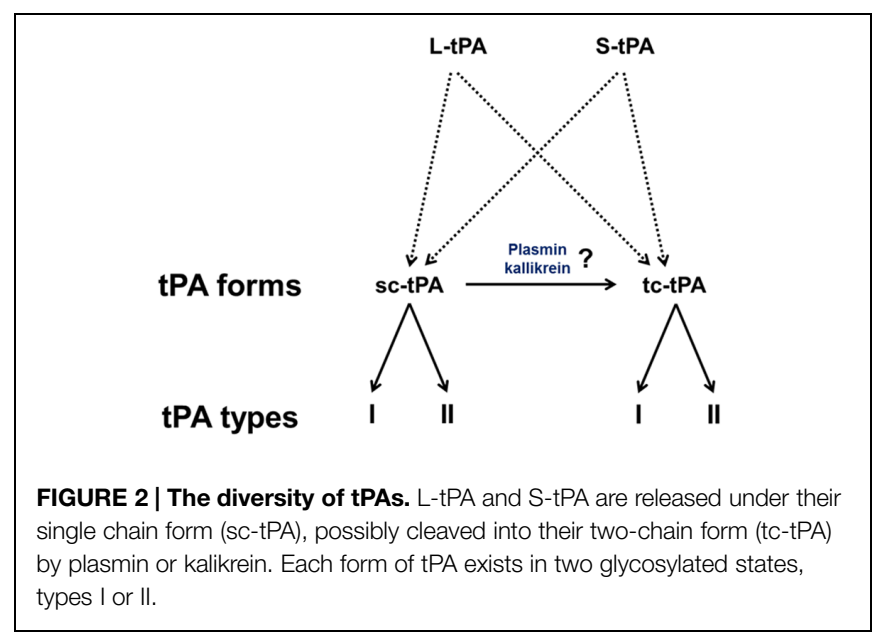

neuronal death induced by both NMDAR- and non-NMDARagonists (Tsirka et al., 1995), an effect dependent of the ability of tPA to activate plasminogen into plasmin (Tsirka et al., 1997a,b; Figure 3A). Accordingly, several studies have reported that inhibitors of tPA, such as neuroserpin and type 1 plasminogen activator inhibitor (PAI-1) protect neurons against toxicity induced by the over-activation of NMDARs (Buisson et al., 1998; Zhang et al., 2002; Gabriel et al., 2003; Lebeurrier et al., 2005). Exogenous tPA was then reported pro-neurotoxic, on cortical neurons, in paradigms of in vitro or in vivo excitotoxicity mediated by over-activation of NMDAR (Nicole et al., 2001; Liberatore et al., 2003; Reddrop et al., 2005; Park et al., 2008; Figure 3B). The tPA was also reported to promote damages on Purkinje cells ( $\mathrm{Lu}$ and Tsirka, 2002; Li et al., 2006, 2013; Cops et al., 2013; Figure 3C), especially by altering the neurotrophic mechanisms that control their postnatal development (Li et al., 2006, 2013).

Both plasmin-dependent and plasmin-independent mechanisms have been proposed to explain the potentiation of NMDAR signaling by tPA (Nicole et al., 2001; Pawlak et al., 2002; Matys and Strickland, 2003), but several recent studies agree that it can occur independently of plasminogen activation (Samson et al., 2008; Echeverry et al., 2010; Parcq et al., 2012). For instance, tPA can interact with the GluN1 subunit of NMDAR involving the LBS of its K2 domain (Nicole et al., 2001; Fernández-Monreal et al., 2004; Kvajo et al., 2004; López-Atalaya et al., 2008; Parcq et al., 2012). Our group reported that the cleavage of the amino-terminal domain of GluN1 subunit is necessary for enhancement of NMDAR signaling by tPA (Nicole et al., 2001; Fernández-Monreal et al., 2004). In the brain of protease nexin-1 (PN-1, an inhibitor of tPA) deficient mice, Kvajo et al. (2004), demonstrated an increase in the proteolytic activity of tPA, correlated with a decrease in the amount of the GluN1 subunit of the NMDA receptor. However, no cleavage of GluN1 was observed despite the interaction of tPA with the GluN1 subunits of NMDAR (Kvajo et al., 2004). Other groups did not detect tPA-dependent cleavage of GluN1, despite enhancement of NMDAR function by exogenous tPA in cortical cultures (Samson et al., 2008). In a more recent study, it was reported that sc-tPA, but not tc-tPA can promote NMDAR signaling and neurotoxicity in cortical neurons (Parcq et al., 2012; Bertrand et al., 2015). These data were the first to describe a differential function of sc-tPA and tc-tPA. tPA would also act on neuronal death by engaging Low density lipoprotein related protein (LRP) receptors, which in turn would enhance $\mathrm{Ca}^{2+}$ downstream of NMDAR (Samson et al., 2008). More recent data obtained from Schwann cells showed that tPA can promote NMDAR signaling independently of LRP1 (Mantuano et al., 2015). Similarly, in PC12 and N2a neuron-like cells, tPA may signal through a complex containing NMDAR, LPR1, and Trk receptors (Mantuano et al., 2013). Plasmin, which is generated by the tPA-dependent conversion of plasminogen, has also been reported to cleave NMDARs, specifically the GluN2 subunit. This cleavage can occur at two sites: Lys317 on GluN2A, which relieves $\mathrm{Zn}^{2+}$ inhibition and thereby increases 


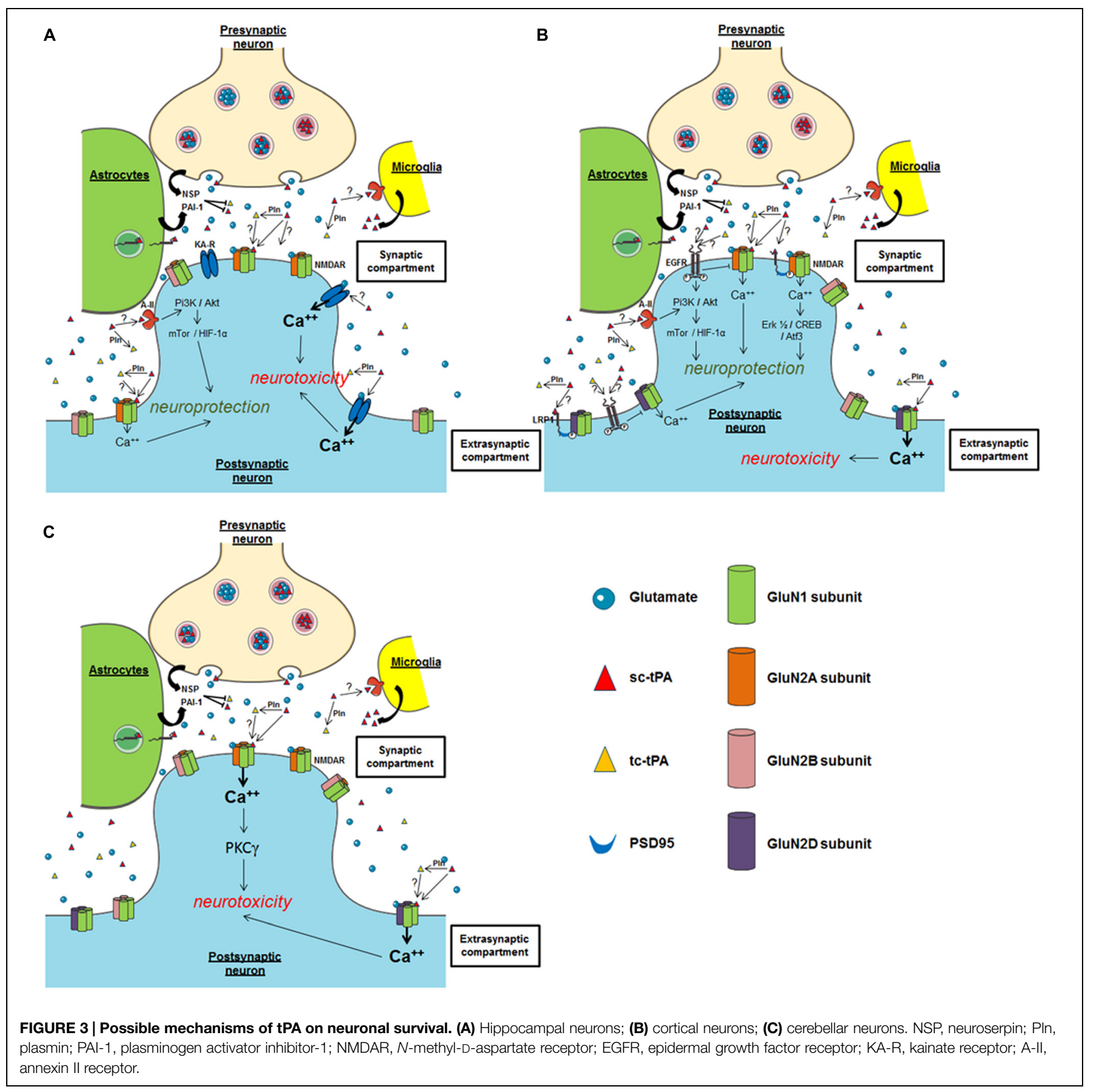

NMDAR function (Yuan et al., 2009), and Arg67 on GluN2B, which increases sensitivity of the NMDAR to glycine $(\mathrm{Ng}$ et al., 2012). Whether tPA-dependent plasmin formation counteracts or interferes with tPA-dependent NMDAR activation is still under debate. Whatever the mechanism, all these studies showed that tPA can increase NMDAR signaling.

By contrast, other studies, in particular using transgenic mice over-expressing tPA in neurons (T4 transgenic mice) or tPA $\mathrm{KO}$ mice, suggested that tPA can also have neuroprotective effects (Haile et al., 2012; Wu et al., 2012). These two studies also proposed a mechanism dependent on the activation of NMDAR and independent on plasmin. In vitro and ex vivo studies also reported pro-survival effects of tPA on neurons (Liot et al., 2006; Lee et al., 2007; Polavarapu et al., 2007; Bertrand et al., 2015; Lemarchand et al., 2015), mainly anti-apoptotic effects. Also interesting, tPA was reported to attenuate zincinduced neuronal cell death independently of its proteolytic action (Kim et al., 1999; Siddiq and Tsirka, 2004). Despite the heterogeneity of the paradigms used in these different studies, they all showed that this effect of tPA occurs independently of its proteolytic activity, with the activation of either PI3K/Akt, 
AMPK- or mTor-HIF-1alpha-dependent signaling pathways needed (Correa et al., 2011; Wu et al., 2012; Figure 3B). Two candidates have been proposed as the receptors mediating the pro-survival effects of tPA: Annexin II and EGF receptor (Siao and Tsirka, 2002; Wu et al., 2012; Bertrand et al., 2015; Lemarchand et al., 2015). The ability of tPA to convert the pro-neurotrophins (BDNF, NGF) to their active forms (Pang et al., 2004) is also a possible explanation to the pro-survival effects of tPA.

\section{WHAT ARE THE POSSIBLE EXPLANATIONS OF THE DIFFERENTIAL EFFECTS OF TPA ON NEURONAL SURVIVAL? (TABLE 1)}

\section{Are Target Receptors the Explanations?}

In the brain parenchyma, pro-survival and pro-neurotoxic effects of tPA have been shown to involve key receptors/pathways, including NMDAR (Nicole et al., 2001), LRP-mediated PSD95 activation (Martin et al., 2008), annexin-II (Siao and Tsirka, 2002), and EGF receptor (Liot et al., 2006; Lemarchand et al., 2015). Focusing on NMDARs, the fact that tPA induces toxic or protective effects could also depend on the different subtypes of GluN subunits involved, and/or their location (synaptic versus extrasynaptic; Paoletti et al., 2013). For instance, based on the current literature, it could be postulated that exogenous tPA could promote neurotoxicity on cortical neurons by activating extrasynaptic GluN2D-containing NMDARs (Baron et al., 2010; Jullienne et al., 2011; Montagne et al., 2012), but could lead to a neuroprotective effect by activating synaptic GluN2A-containing NMDARs (Wu et al., 2013a; Figure 3B). Several studies also propose that the neuroprotective activity of tPA, even in a paradigm involving NMDARs, is NMDAR-independent (Correa et al., 2011), independent of its proteolytic activity (Liot et al., 2006). In a model of apoptosis induced by serum deprivation (Liot et al., 2006) or when subjected to OGD, the neuroprotective effect of tPA is mediated by an activation of either EGFR (Correa et al., 2011; Bertrand et al., 2015; Lemarchand et al., 2015) or annexin II (Lee et al., 2007). Whether LRP is also involved is still under debate, again dependent on the paradigm used (Martin et al., 2008). Up to now, it is not clear how these different receptors contribute to the differential effects of tPA in neuronal survival. Additional studies are needed including investigations about possible crosstalks between these different receptors.

\section{Are Protocols of Neuronal Injury the Explanation?}

Type plasminogen activator-dependent over-activation of NMDARs has been proposed as a mechanism that could mediate both neuroprotective (Wu et al., 2013b) and neurotoxic (Baron et al., 2010) effects of tPA (Figure 3B). This discrepancy may be explained by the use of different models to induce neuronal death, either pure NMDAR-mediated excitotoxicity (Baron et al.,
2010) or oxygen glucose deprivation (OGD; Wu et al., 2013b). Whether OGD induces excitotoxicity and/or apoptosis is not well documented and might depend on the severity/duration of the stress. Pathways such as autophagy or endoplasmic reticulum stress may also occur (Badiola et al., 2011; Shi et al., 2012). Another explanation could be the use of differential strategies to block tPA-induced potentiation of NMDAR signaling, MK-801 as a broad irreversible antagonist of NMDARs on one hand (Terro et al., 2000) and an antibody previously characterized to specifically prevent the tPA-dependent potentiation of NMDARs signaling without affecting their basal activity (Benchenane et al., 2007; Macrez et al., 2010) on the other hand. It is interesting to note that either over-activation and blockage of NMDARs are neurotoxic, the first one leading to excitotoxic neuronal death (Nicole et al., 2001), the second one inducing apoptosis (Mattson and Duan, 1999; Henry et al., 2013).

\section{Is Neuronal Maturity an Explanation?}

To discuss the differential impact of tPA on neuronal survival, how neurons are mature is also an important issue including whether experiments were performed in vitro (neuronal cultures performed from E16 embryo and maintained different times in vitro, 5-14 days (Buisson et al., 1998; Samson et al., 2008), ex vivo (hippocampal slices harvested at P3 and maintained different times in vitro; Lemarchand et al., 2015) or in vivo (young versus aged animals; Roussel et al., 2009). For example, it was well-demonstrated that mouse primary cultures of cortical neurons become sensitive to NMDA-induced neuronal death only after 10 days in vitro, an effect potentiated by exogenous tPA (Launay et al., 2008). At early times (days in vitro), they require trophic factors contained in the culture media (serum) to survive (Hetman et al., 2000; Terro et al., 2000). When removed, serum deprivation led to neuronal apoptosis with a protective effect of exogenous tPA (Liot et al., 2006). Type of neurons may also be critical, with neurotoxic effects of tPA mainly described in cortical neurons (Nicole et al., 2001) or Purkinje neurons (Cops et al., 2013; Li et al., 2013; Figures 3B,C). The protective effect of tPA was described on hippocampal neurons (Flavin and Zhao, 2001; Echeverry et al., 2010; Lemarchand et al., 2015; Figure 3A) and on cortical neurons (Liot et al., 2006; Wu et al., 2013a; Figure 3B).

\section{Does the Origin of tPA (Endogenous vs. Exogenous) make the Difference?}

Another important point of discussion is to know whether exogenous and endogenous tPA have differential effects on neuronal survival. The most recent literature in this field demonstrates that endogenous tPA displays neuroprotective activities (Wu et al., 2013a; Lemarchand et al., 2015) and exogenous tPA is neurotoxic (Parcq et al., 2012). Nevertheless, using tPA deficient mice, exogenous tPA may also protect hippocampal neurons subjected to OGD (Lemarchand et al., 2015). These data suggest that tPA (exogenous or endogenous) may have either pro-neurotoxic or pro-survival effects depending of the type of 


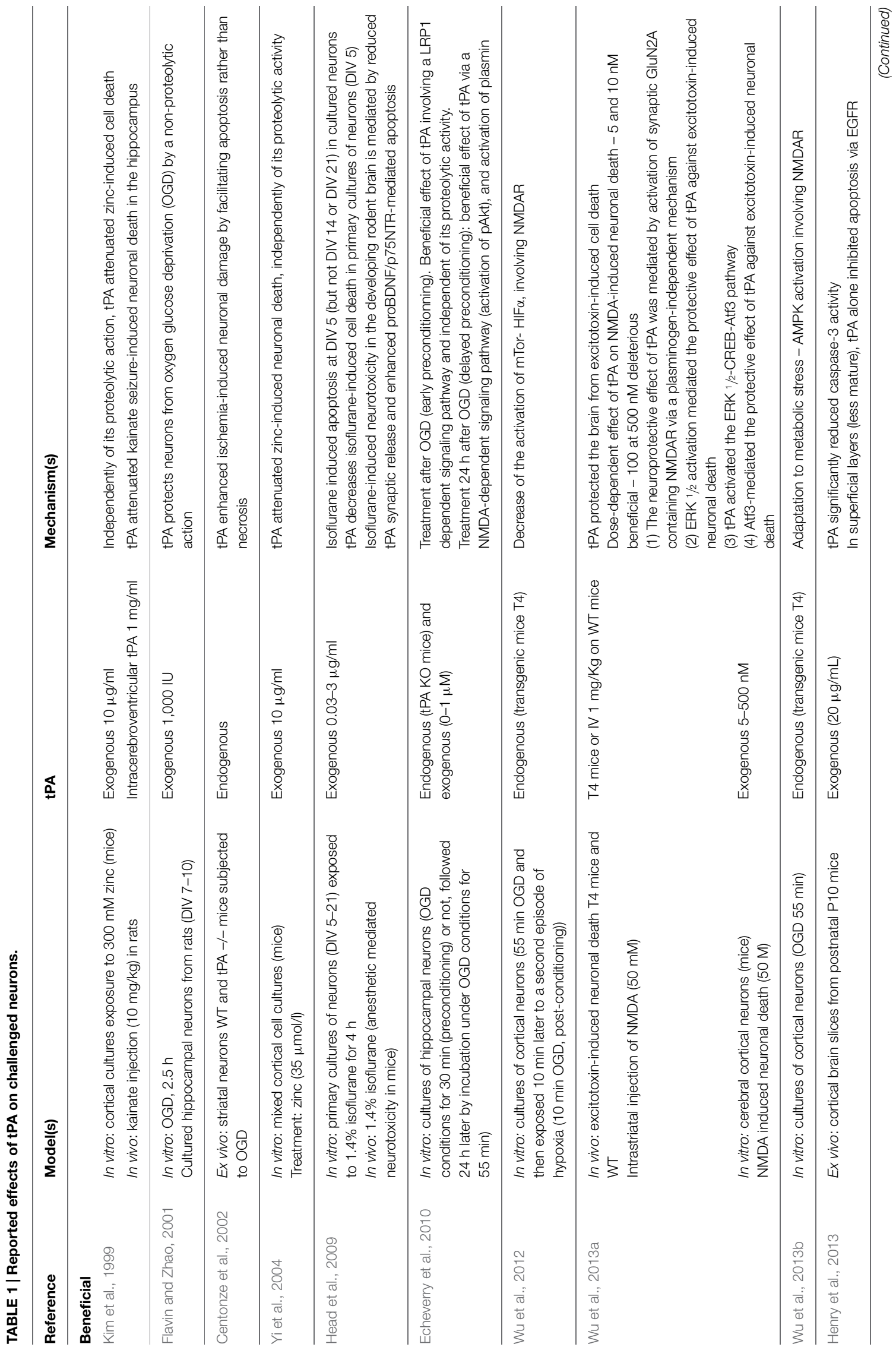




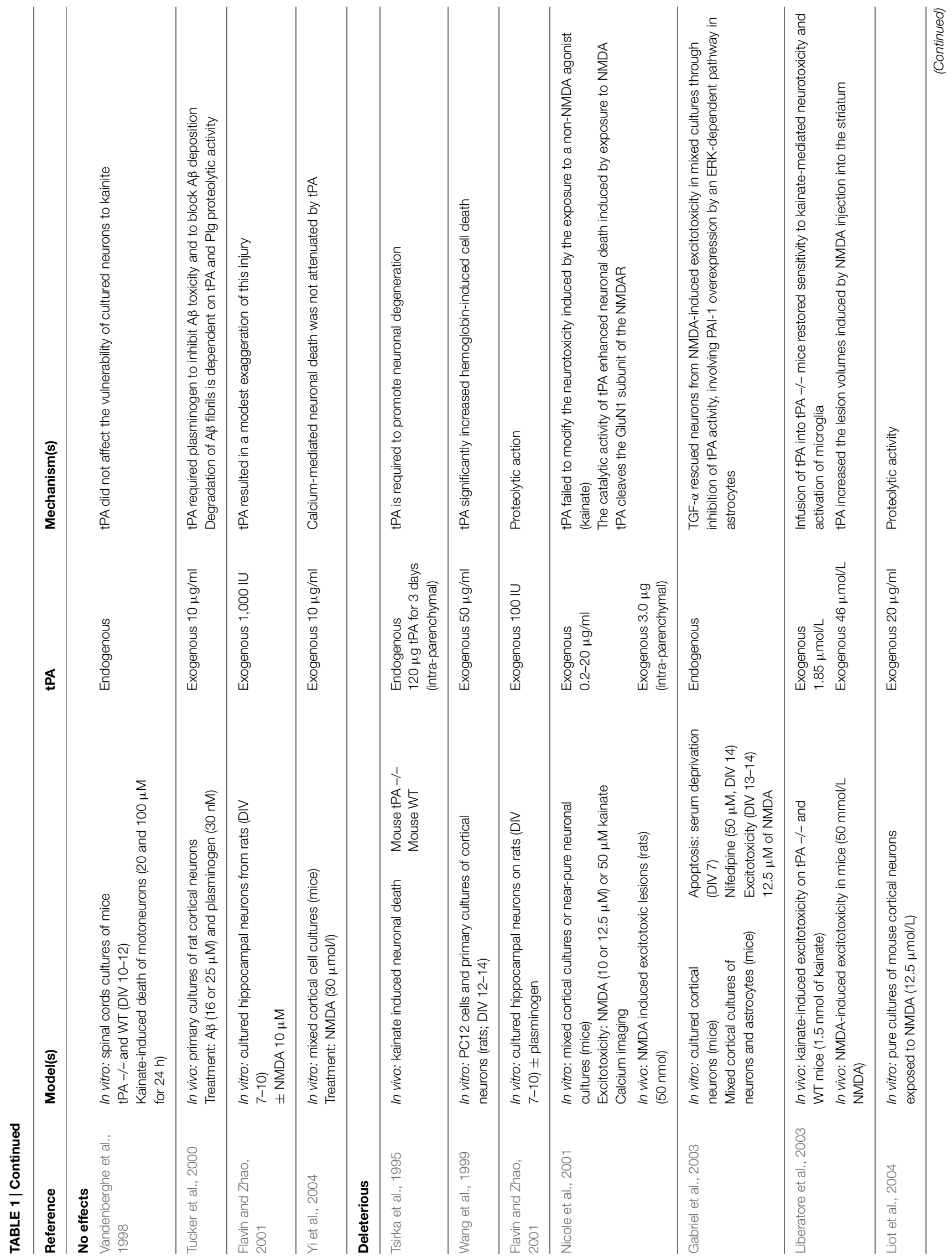




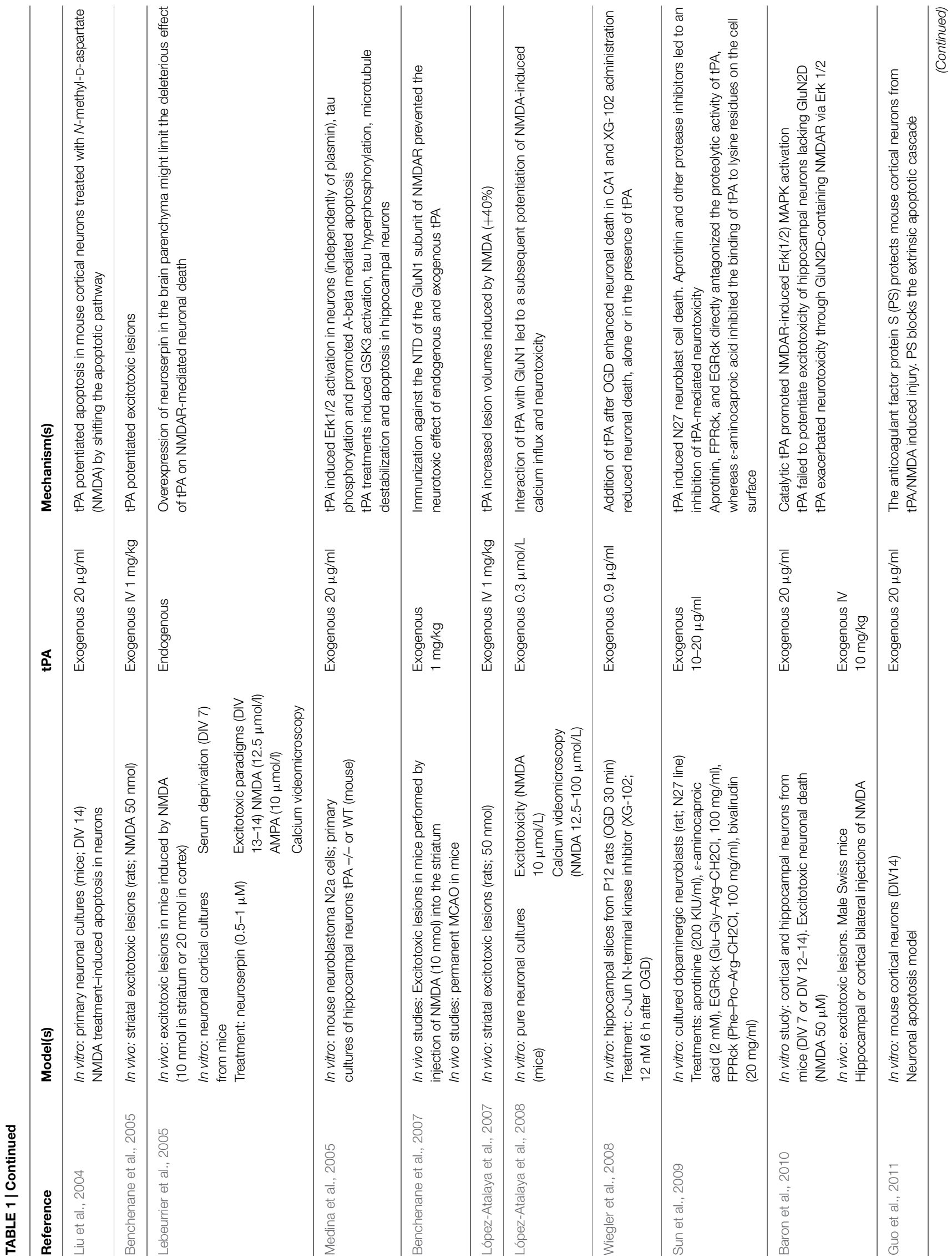




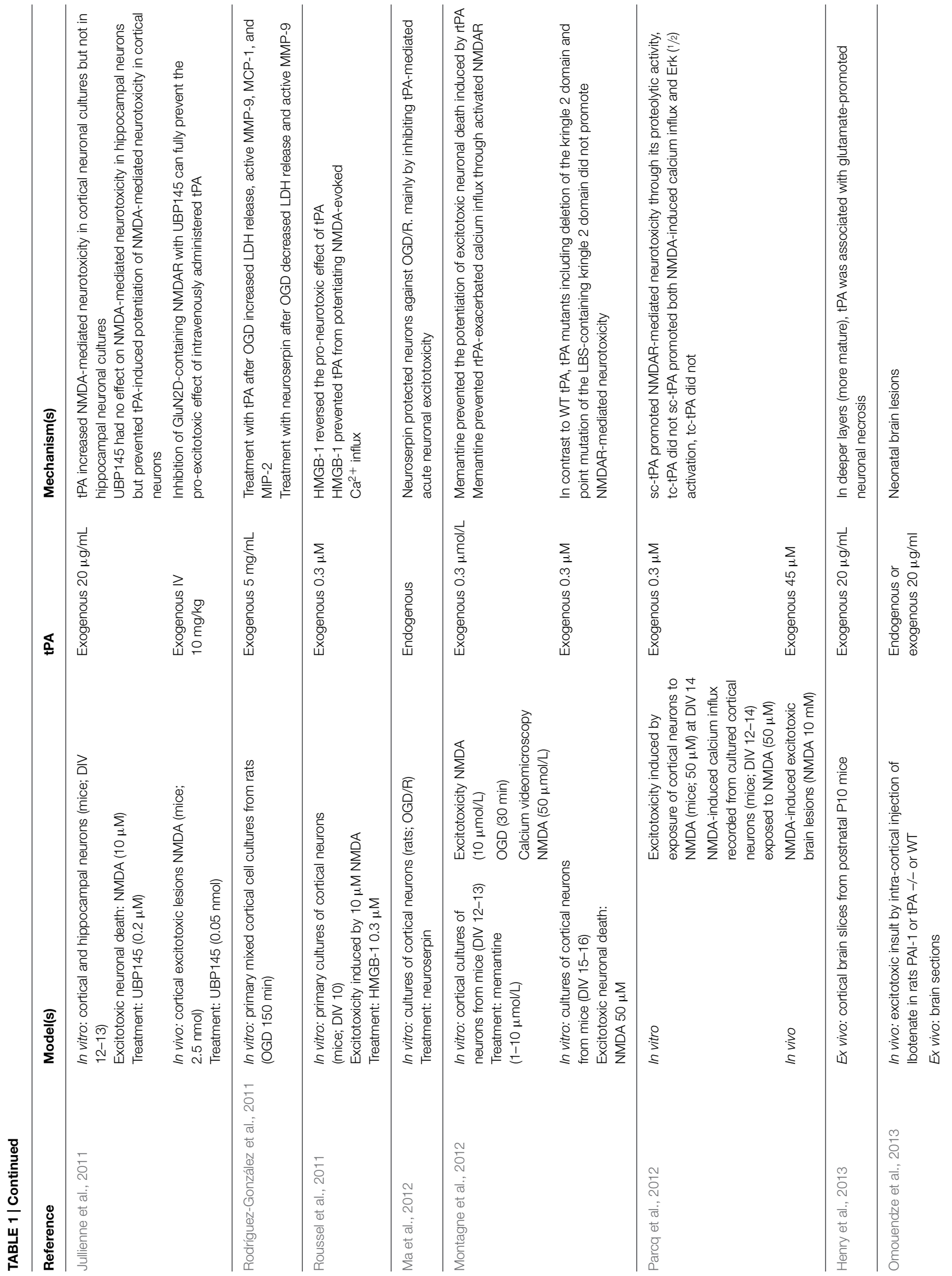


stress paradigms used and/or the type of neurons. Thus, whether experiments are performed on wild type neurons, tPA deficient neurons, tPA over-expressing neurons, in vitro and in vivo, is important to understand the impacts of tPA on neuronal survival (Tsirka et al., 1995; Wang et al., 1998; Nicole et al., 2001; Liot et al., 2006; Echeverry et al., 2010; Wu et al., 2013a).

\section{WHAT ABOUT THE LEVEL OF tPA?}

Some authors suggest that low levels of tPA are neuroprotective (Wu et al., 2013a), either exogenous (Baron et al., 2010) or produced by stressed cells (Lemarchand et al., 2015). In contrast, high levels of tPA (mainly exogenous) are neurotoxic (Nicole et al., 2001; Parcq et al., 2012).

\section{Finally, Why not the Form of tPA?}

There is so far only one study which discriminated tPA isoforms in the context of neuronal survival, with a clear evidence that sc-tPA is the only one capable to activate NMDAR and to promote excitotoxicity (in mouse cortical neurons subjected to NMDA exposure) both in vitro and in vivo (Parcq et al., 2012; Bertrand et al., 2015). It is thus interesting to note, that complexes formed between sc-tPA and neuroserpin (NSP) were reported more stable than those formed between tc-tPA and NSP, with no differences when complexes are formed with PAI-1 (BarkerCarlson et al., 2002). Whether conversion of sc-tPA into tc-tPA (by plasmin like activity) may influence the functions of tPA on neuronal survival, especially in the context of brain injuries, need to be investigated.

\section{REFERENCES}

Astrup, T., and Permin, P. M. (1947). Fibrinolysis in the animal organism. Nature 159:681. doi: 10.1038/159681b0

Astrup, T., and Stage, A. (1952). Isolation of a soluble fibrinolytic activator from animal tissue. Nature 170:929. doi: 10.1038/170 $929 \mathrm{a} 0$

Badiola, N., Penas, C., Miñano-Molina, A., Barneda-Zahonero, B., Fadó, R., Sánchez-Opazo, et al. (2011). Induction of ER stress in response to oxygenglucose deprivation of cortical cultures involves the activation of the PERK and IRE-1 pathways and of caspase-12. Cell Death Dis. 2:e149. doi: 10.1038/cddis.2011.31

Barker-Carlson, K., Lawrence, D. A., and Schwartz, B. S. (2002). Acylenzyme complexes between tissue-type plasminogen activator and neuroserpin are short-lived in Vitro. J. Biol. Chem. 277, 46852-46857. doi: 10.1074/jbc.M207740200

Baron, A., Montagne, A., Cassé, F., Launay, S., Maubert, E., Ali, C., et al. (2010). NR2D-containing NMDA receptors mediate tissue plasminogen activator-promoted neuronal excitotoxicity. Cell Death Differ. 17, 860-871. doi: $10.1038 /$ cdd.2009.172

Benchenane, K., Berezowski, V., Ali, C., Fernández-Monreal, M., LópezAtalaya, J. P., Brillault, J., et al. (2005). Tissue-type plasminogen activator crosses the intact blood-brain barrier by low-density lipoprotein receptorrelated protein-mediated transcytosis. Circulation 111, 2241-2249. doi: 10.1161/01.CIR.0000163542.48611.A2

Benchenane, K., Castel, H., Boulouard, M., Bluthé, R., Fernández-Monreal, M., Roussel, B. D., et al. (2007). Anti-NR1 N-terminal-domain vaccination unmasks the crucial action of tPA on NMDA-receptor-mediated toxicity and spatial memory. J. Cell Sci. 120, 578-585. doi: 10.1242/jcs.03354

\section{CONCLUSION}

Depending on the study, endogenous tPA was reported as deleterious or beneficial for neurons. Although it is difficult to reconcile these findings, some propose that tPA is neuroprotective at low levels, but neurotoxic at higher levels. Assays of extracellular levels of tPA under specific conditions should be provided to support this hypothesis. Undoubtedly, the target involved is also a key trigger in the effect of tPA. In general, the pro-survival effects of tPA are independent on its proteolytic activity involving, interconnected or independently, EGF receptors, annexin II, PI-3 kinase-, AMPK-, mTor-HIF-1alpha-dependent signaling pathways. In the adult, the neurotoxic effects of tPA seem to be dependent on its proteolytic activity, targeting either plasminogen, NMDARs, components of the extracellular matrix, inflammatory mediators, and/or other proteases. However, indirect neurotoxicity might also occur via a non-proteolytic activation of microglia (Siao and Tsirka, 2002). For now, there is no clear clinical data to determine, in human, whether tPA is neurotrophic or neurotoxic and in what conditions. Additional studies are needed to understand further the possible differential functions of tPA on neuronal survival. To address this question, we should consider the different isoforms of tPA (type I sc-tPA, type I tc-tPA, type II sc-tPA, and type II tc-tPA), the possibility that tPA may activate its substrates and/or receptors with differential affinities and that these substrates and/or receptors could be differentially expressed in cortical versus hippocampal neurons depending on their maturity.

Berg, D. T., Burck, P. J., Berg, D. H., and Grinnell, B. W. (1993). Kringle glycosylation in a modified human tissue plasminogen activator improves functional properties. Blood 81, 1312-1322.

Berg, D. T., and Grinnell, B. W. (1991). Signal and propeptide processing of human tissue plasminogen activator: activity of a pro-tPA derivative. Biochem. Biophys. Res. Commun. 179, 1289-1296. doi: 10.1016/0006-291X(91)91713-M

Bertrand, T., Lesept, L., Chevilley, A., Lenoir, S., Aimable, M., Briens, A., et al. (2015). Conformations of tissue plasminogen activator (tPA) orchestrate neuronal survival by a crosstalk between EGFR and NMDAR. Cell Death Dis. (in press).

Binder, B. R., Spragg, J., and Austen, K. F. (1979). Purification and characterization of human vascular plasminogen activator derived from blood vessel perfusates. J. Biol. Chem. 254, 1998-2003.

Boose, J. A., Kuismanen, E., Gerard, R., Sambrook, J., and Gething, M. J. (1989). The single-chain form of tissue-type plasminogen activator has catalytic activity: studies with a mutant enzyme that lacks the cleavage site. Biochemistry 28, 635-643. doi: 10.1021/bi00428a033

Borisov, O. V., Field, M., Ling, V. T., and Harris, R. J. (2009). Characterization of oligosaccharides in recombinant tissue plasminogen activator produced in Chinese hamster ovary cells: two decades of analytical technology development. Anal. Chem. 81, 9744-9754. doi: 10.1021/ ac901498k

Buisson, A., Nicole, O., Docagne, F., Sartelet, H., Mackenzie, E. T., and Vivien, D. (1998). Up-regulation of a serine protease inhibitor in astrocytes mediates the neuroprotective activity of transforming growth factor betal. FASEB J. 12, 1683-1691.

Campbell, B. C. V., Mitchell, P. J., Kleinig, T. J., Dewey, H. M., Churilov, L., Yassi, N., et al. (2015). Endovascular therapy for ischemic stroke with perfusion-imaging selection. N. Engl. J. Med. 372, 1009-1018. doi: 10.1056/NEJMoa1414792 
Cassé, F., Bardou, I., Danglot, L., Briens, A., Montagne, A., Parcq, J., et al. (2012). Glutamate controls tPA recycling by astrocytes, which in turn influences glutamatergic signals. J. Neurosci. 32, 5186-5199. doi: 10.1523/JNEUROSCI.5296-11.2012

Centonze, D., Saulle, E., Pisani, A., Bonsi, P., Tropepi, D., Bernardi, G., et al. (2002). Tissue plasminogen activator is required for striatal post-ischemic synaptic potentiation. Neuroreport 13, 115-118. doi: 10.1097/00001756-20020121000027

Christensen, L. R., and Macleod, C. M. (1945). A proteolytic enzyme of serum: characterization, activation, and reaction with inhibitors. J. Gen. Physiol. 28, 559-583. doi: 10.1085/jgp.28.6.559

Collen, D., and Lijnen, H. R. (1991). Basic and clinical aspects of fibrinolysis and thrombolysis. Blood 78, 3114-3124.

Collen, D., and Lijnen, H. R. (2009). The tissue-type plasminogen activator story. Arterioscler. Thromb. Vasc. Biol. 29, 1151-1155. doi: 10.1161/ATVBAHA.108.179655

Collen, D., Rijken, D. C., Van Damme, J., and Billiau, A. (1982). Purification of human tissue-type plasminogen activator in centigram quantities from human melanoma cell culture fluid and its conditioning for use in vivo. Thromb. Haemost. 48, 294-296.

Conradi, H. (1902). Über die Beziehung der Autolyse zur Blutgerinnung. Beitr. chem. Physiol. Path. 1:136.

Cops, E. J., Sashindranath, M., Daglas, M., Short, K. M., da Fonseca Pereira, C., Pang, T. Y., et al. (2013). Tissue-type plasminogen activator is an extracellular mediator of Purkinje cell damage and altered gait. Exp. Neurol. 249, 8-19. doi: 10.1016/j.expneurol.2013.08.001

Correa, F., Gauberti, M., Parcq, J., Macrez, R., Hommet, Y., Obiang, P., et al. (2011). Tissue plasminogen activator prevents white matter damage following stroke. J. Exp. Med. 208, 1229-1242. doi: 10.1084/jem.20101880

Denis, P. S. (1838). Essai sur l'Application de la Chimie a l'Etude Physiologique Du sang de l'Homme. Paris: JB Ballièere.

Denys, J., and de Marbaix, H. (1889). Les peptonisations provoquees par le chloroforme. Cellule 5, 197-251.

Echeverry, R., Wu, J., Haile, W. B., Guzman, J., and Yepes, M. (2010). Tissue-type plasminogen activator is a neuroprotectant in the mouse hippocampus. J. Clin. Invest. 120, 2194-2205. doi: 10.1172/JCI41722.2194

Einarsson, M., Brandt, J., and Kaplan, L. (1985). Large-scale purification of human tissue-type plasminogen activator using monoclonal antibodies. Biochim. Biophys. Acta 830, 1-10. doi: 10.1016/0167-4838(85)90123-2

Fernández-Monreal, M., López-Atalaya, J. P., Benchenane, K., Cacquaevel, M., Dulin, F., Le Caer, J. P., et al. (2004). Arginine 260 of the aminoterminal domain of NR1 subunit is critical for tissue-type plasminogen activator-mediated enhancement of N-methyl-D-aspartate receptor signaling. J. Biol. Chem. 279, 50850-50856. doi: 10.1074/jbc.M40 7069200

Flavin, M. P., and Zhao, G. (2001). Hippocampal neurons from oxygenglucose deprivation injury. J. Neurosci. Res. 63, 388-394. doi: 10.1002/10974547(20010301)63:5

Fleisher, M. S., and Loeb, L. (1915). Further investigations on the mode of action of substances inhibiting tumor grozcth and on immunisation against these substances. J. Exp. Med. 21, 155-163. doi: 10.1084/jem.21.2.155

Fredriksson, L., Li, H., Fieber, C., Li, X., and Eriksson, U. (2004). Tissue plasminogen activator is a potent activator of PDGF-CC. EMBO J. 23, 37933802. doi: 10.1038/sj.emboj.7600397

Gabriel, C., Ali, C., Lesné, S., Fernández-Monreal, M., Docagne, F., Plawinski, L., et al. (2003). Transforming growth factor alpha-induced expression of type 1 plasminogen activator inhibitor in astrocytes rescues neurons from excitotoxicity. FASEB J. 17, 277-279. doi: 10.1096/fj.020403fje

Goyal, M., Demchuk, A. M., Menon, B. K., Eesa, M., Rempel, J. L., Thornton, J., et al. (2015). Randomized assessment of rapid endovascular treatment of ischemic stroke. N. Engl. J. Med. 372, 1019-1030. doi: 10.1056/NEJMoa141 4905

Guo, H., Barrett, T. M., Zhong, Z., Fernández, J. A., Griffin, J. H., Freeman, R. S., et al. (2011). Protein S blocks the extrinsic apoptotic cascade in tissue plasminogen activator/N-methyl D-aspartate-treated neurons via Tyro3-AktFKHRL1 signaling pathway. Mol. Neurodegener. 6:13. doi: 10.1186/1750-13266-13
Haile, W. B., Wu, J., Echeverry, R., Wu, F., An, J., and Yepes, M. (2012). Tissuetype plasminogen activator has a neuroprotective effect in the ischemic brain mediated by neuronal TNF- $\alpha$. J. Cereb. Blood Flow Metab. 32, 57-69. doi: 10.1038/jcbfm.2011.106

Hajjar, K. A., and Reynolds, C. M. (1994). alpha-Fucose-mediated binding and degradation of tissue-type plasminogen activator by HepG2 cells. J. Clin. Invest. 93, 703-710. doi: 10.1172/JCI117023

Harris, R. J., Leonard, C. K., Guzzetta, A. W., and Spellman, M. W. (1991). Tissue plasminogen activator has an O-linked fucose attached to threonine61 in the epidermal growth factor domain. Biochemistry 30, 2311-2314. doi: 10.1021/bi00223a004

Head, B. P., Patel, H. H., Niesman, I. R., Drummond, J. C., Roth, D. M., and Patel, P. M. (2009). Inhibition of p75 neurotrophin receptor attenuates isoflurane-mediated neuronal apoptosis in the neonatal central nervous system. Anesthesiology 110, 813-825. doi: 10.1097/ALN.0b013e318 $19 \mathrm{~b} 602 \mathrm{~b}$

Hedin, S. G. (1903). On the presence of a proteolytic enzyme in the normal serum of the ox. J. Physiol. 30, 195-201. doi: 10.1113/jphysiol.1903.sp000989

Henry, V. J., Lecointre, M., Laudenbach, V., Ali, C., Macrez, R., Jullienne, A., et al. (2013). High t-PA release by neonate brain microvascular endothelial cells under glutamate exposure affects neuronal fate. Neurobiol. Dis. 50, 201-208. doi: 10.1016/j.nbd.2012.10.020

Hetman, M., Cavanaugh, J. E., Kimelman, D., and Xia, Z. (2000). Role of glycogen synthase kinase-3beta in neuronal apoptosis induced by trophic withdrawal. J. Neurosci. 20, 2567-2574.

Ichinose, A., Kisiel, W., and Fujikawa, K. (1984). Proteolytic activation of tissue plasminogen activator by plasma and tissue enzymes. FEBS Lett. 175, 412-418. doi: 10.1016/0014-5793(84)80779-6

Jaques, A. J., Opdenakker, G., Rademacher, T. W., Dwek, R. A., and Zamze, S. E. (1996). The glycosylation of Bowes melanoma tissue plasminogen activator: lectin mapping, reaction with anti-L2/HNK-1 antibodies and the presence of sulphated/glucuronic acid containing glycans. Biochem. J. 316, 427-437. doi: 10.1042/bj3160427

Jörnvall, H., Pohl, G., Bergsdorf, N., and Wallén, P. (1983). Differential proteolysis and evidence for a residue exchange in tissue plasminogen activator suggest possible association between two types of protein microheterogeneity. FEBS Lett. 156, 47-50. doi: 10.1016/0014-5793(83) 80245-2

Jullienne, A., Montagne, A., Orset, C., Lesept, F., Jane, D. E., Monaghan, D. T., et al. (2011). Selective inhibition of GluN2D-containing N-methyl-D-aspartate receptors prevents tissue plasminogen activator-promoted neurotoxicity both in vitro and in vivo. Mol. Neurodegener. 6:68. doi: 10.1186/17501326-6-68

Kim, H. K., Lee, S. Y., Oh, H. K., Kang, B. H., Ku, H. J., Lee, Y., et al. (2003). Inhibition of endothelial cell proliferation by the recombinant kringle domain of tissue-type plasminogen activator. Biochem. Biophys. Res. Commun. 304, 740-746. doi: 10.1016/S0006-291X(03)00656-9

Kim, Y., Park, J. H., Hong, S. H., and Koh, J. Y. (1999). Nonproteolytic neuroprotection by human recombinant tissue plasminogen activator. Science 284, 647-650. doi: 10.1126/science.284.5414.647

Kuiper, J., Van't Hof, A., Otter, M., Biessen, E. A., Rijken, D. C., and van Berkel, T. J. (1996). Interaction of mutants of tissue-type plasminogen activator with liver cells: effect of domain deletions. Biochem. J. 313, 775-780. doi: 10.1042/bj3130775

Kvajo, M., Albrecht, H., Meins, M., Hengst, U., Troncoso, E., Lefort, S., et al. (2004). Regulation of brain proteolytic activity is necessary for the in vivo function of NMDA receptors. J. Neurosci. 24, 9734-9743. doi: 10.1523/JNEUROSCI.330604.2004

Lamba, D., Bauer, M., Huber, R., Fischer, S., Rudolph, R., Kohnert, U., et al. (1996). The 2.3 A crystal structure of the catalytic domain of recombinant twochain human tissue-type plasminogen activator. J. Mol. Biol. 258, 117-135. doi: 10.1006/jmbi.1996.0238

Larsen, G. R., Henson, K., and Blue, Y. (1988). Variants of human tissue-type plasminogen activator. . J. Biol. Chem. 263, 1023-1029.

Launay, S., Maubert, E., Lebeurrier, N., Tennstaedt, A., Campioni, M., Docagne, F., et al. (2008). HtrA1-dependent proteolysis of TGF-beta controls both neuronal maturation and developmental survival. Cell Death Differ. 15, 1408-1416. doi: $10.1038 / \mathrm{cdd} .2008 .82$ 
Lebeurrier, N., Liot, G., Lopez-Atalaya, J. P., Orset, C., Fernandez-Monreal, M., Sonderegger, P., et al. (2005). The brain-specific tissue-type plasminogen activator inhibitor, neuroserpin, protects neurons against excitotoxicity both in vitro and in vivo. Mol. Cell. Neurosci. 30, 552-558. doi: 10.1016/j.men.2005.09.005

Lee, H. Y., Hwang, I. Y., Im, H., Koh, J. Y., and Kim, Y. H. (2007). Non-proteolytic neurotrophic effects of tissue plasminogen activator on cultured mouse cerebrocortical neurons. J. Neurochem. 101, 1236-1247. doi: 10.1111/j.14714159.2007.04417.x

Lemarchand, E., Maubert, E., Haelewyn, B., Ali, C., Rubio, M., and Vivien, D. (2015). Stressed neurons protect themselves by a tissue-type plasminogen activator-mediated EGFR-dependent mechanism. Cell Death Differ. doi: 10.1038/cdd.2015.76 [Epub ahead of print].

Li, J., Ma, Y., Teng, Y. D., Zheng, K., Vartanian, T. K., Snyder, E. Y., et al. (2006). Purkinje neuron degeneration in nervous (nr) mutant mice is mediated by a metabolic pathway involving excess tissue plasminogen activator. Proc. Natl. Acad. Sci. U.S.A. 103, 7847-7852. doi: 10.1073/pnas.0602 440103

Li, J., Yu, L., Gu, X., Ma, Y., Pasqualini, R., Arap, W., et al. (2013). Tissue plasminogen activator regulates Purkinje neuron development and survival. Proc. Natl. Acad. Sci. U.S.A. 110, E2410-E2419. doi: 10.1073/pnas.1305 010110

Liberatore, G. T., Samson, A., Bladin, C., Schleuning, W. D., and Medcalf, R. L. (2003). Vampire bat salivary plasminogen activator (desmoteplase): a unique fibrinolytic enzyme that does not promote neurodegeneration. Stroke 34, 537543. doi: 10.1161/01.STR.0000049764.49162.76

Liot, G., Benchenane, K., Léveillé, F., López-Atalaya, J. P., Fernández-Monreal, M., Ruocco, A., et al. (2004). 2,7-Bis-(4-amidinobenzylidene)-cycloheptan1-one dihydrochloride, tPA stop, prevents tPA-enhanced excitotoxicity both in vitro and in vivo. J. Cereb. Blood Flow Metab. 24, 1153-1159. doi: 10.1097/01.WCB.0000134476.93809.75

Liot, G., Roussel, B. D., Lebeurrier, N., Benchenane, K., López-Atalaya, J. P., Vivien, D., et al. (2006). Tissue-type plasminogen activator rescues neurones from serum deprivation-induced apoptosis through a mechanism independent of its proteolytic activity. J. Neurochem. 98, 1458-1464. doi: 10.1111/j.14714159.2006.03982.x

Liu, D., Cheng, T., Guo, H., Fernández, J. A., Griffin, J. H., Song, X., et al. (2004). Tissue plasminogen activator neurovascular toxicity is controlled by activated protein C. Nat. Med. 10, 1379-1383. doi: 10.1038/nm1122

López-Atalaya, J. P., Roussel, B. D., Ali, C., Maubert, E., Petersen, K. U., Berezowski, V., et al. (2007). Recombinant Desmodus rotundus salivary plasminogen activator crosses the blood-brain barrier through a lowdensity lipoprotein receptor-related protein-dependent mechanism without exerting neurotoxic effects. Stroke 38, 1036-1043. doi: 10.1161/01.STR.0000258100.04923.84

López-Atalaya, J. P., Roussel, B. D., Levrat, D., Parcq, J., Nicole, O., Hommet, Y., et al. (2008). Toward safer thrombolytic agents in stroke: molecular requirements for NMDA receptor-mediated neurotoxicity. J. Cereb. Blood Flow Metab. 28, 1212-1221. doi: 10.1038/jcbfm.2008.14

Lu, W., and Tsirka, S. E. (2002). Partial rescue of neural apoptosis in the Lurcher mutant mouse through elimination of tissue plasminogen activator. Development 129, 2043-2050.

Ma, J., Yu, D., Tong, Y., and Mao, M. (2012). Effect of neuroserpin in a neonatal hypoxic-ischemic injury model ex vivo. Biol. Res. 45, 357-362. doi: 10.4067/S0716-97602012000400005

Macfarlane, R. G., and Biggs, R. (1948). Fibrinolysis; its mechanism and significance. Blood 3, 1167-1187.

Macrez, R., Bezin, L., Le Mauff, B., Ali, C., and Vivien, D. (2010). Functional occurrence of the interaction of tissue plasminogen activator with the NR1 Subunit of N-methyl-D-aspartate receptors during stroke. Stroke. 41, 29502955. doi: 10.1161/STROKEAHA.110.592360

Madison, E. L., Kobe, A., Gething, M. J., Sambrook, J. F., and Goldsmith, E. J. (1993). Converting tissue plasminogen activator to a zymogen: a regulatory triad of Asp-His-Ser. Science 262, 419-421. doi: 10.1126/science.8211162

Mantuano, E., Lam, M. S., and Gonias, S. L. (2013). LRP1 assembles unique co-receptor systems to initiate cell-signaling in response to tissue-type plasminogen activator and myelin-associated glycoprotein. J. Biol. Chem. 288, 34009-34018. doi: 10.1074/jbc.M113.509133
Mantuano, E., Lam, M. S., Shibayama, M., Campana, W. M., and Gonias, S. L. (2015). The NMDA receptor functions independently and as an LRP1 coreceptor to promote Schwann cell survival and migration. J. Cell Sci. 128, 3478-3488. doi: 10.1242/jcs. 173765

Martin, A. M., Kuhlmann, C., Trossbach, S., Jaeger, S., Waldron, E., Roebroek, A., et al. (2008). The functional role of the second NPXY motif of the LRP1 $\beta$-chain in tissue-type plasminogen activator-mediated activation of N-methyl-D-aspartate receptors. J. Biol. Chem. 283, 12004-12013. doi: 10.1074/jbc.M707607200

Mattson, M. P., and Duan, W. (1999). “Apoptotic” biochemical cascades in synaptic compartments: roles in adaptive plasticity and neurodegenerative disorders. J. Neurosci. Res. 58, 152-166. doi: 10.1002/(SICI)1097-4547(19991001)58

Matys, T., and Strickland, S. (2003). Tissue plasminogen activator and NMDA receptor cleavage. Nat. Med. 9, 371-372. doi: 10.1038/nm0403-371

Medina, M. G., Ledesma, M. D., Domínguez, J. E., Medina, M., Zafra, D., Alameda, F., et al. (2005). Tissue plasminogen activator mediates amyloidinduced neurotoxicity via Erk1/2 activation. EMBO J. 24, 1706-1716. doi: 10.1038/sj.emboj.7600650

Montagne, A., Hébert, M., Jullienne, A., Lesept, F., Le Béhot, A., Louessard, M., et al. (2012). Memantine improves safety of thrombolysis for stroke. Stroke 43, 2774-2781. doi: 10.1161/STROKEAHA.112.669374

Morgagni, J. B. (1761). De Sedibus, et Causis Morborum per Anatomen Indagatis. Venezia: Remondini.

Mori, K., Dwek, R. A., Downing, K. A., Opdenakker, G., Pauline, M., and Rudd, P. M. (1995). The activation of Type 1 and Type 2 plasminogen by Type I and Type II tissue plasminogen activator. Biochem. J. 270, 3261-3267. doi: $10.1074 /$ jbc.270.7.3261

Ng, K. S., Leung, H. W., Wong, P. T. H., and Low, C. M. (2012). Cleavage of the NR2B subunit amino terminus of N-methyl-D-aspartate (n.d.) Receptor by tissue plasminogen activator: identification of the cleavage site and characterization of ifenprodil and glycine affinities on truncated NMDA receptor. J. Biol. Chem. 287, 25520-25529. doi: 10.1074/jbc.M112.374397

Nicole, O., Docagne, F., Ali, C., Margaill, I., Carmeliet, P., MacKenzie, E. T., et al. (2001). The proteolytic activity of tissue-plasminogen activator enhances NMDA receptor-mediated signaling. Nat. Med. 7, 59-64. doi: 10.1038/83358

NINDS (1995). Tissue plasminogen activator for acute ischemic stroke. N. Engl. J. Med. 333, 1581-1587. doi: 10.1056/NEJM199512143332401

Omouendze, P. L., Henry, V. J., Porte, B., Dupré, N., Carmeliet, P., Gonzalez, B. J., et al. (2013). Hypoxia-ischemia or excitotoxin-induced tissue plasminogen activator- dependent gelatinase activation in mice neonate brain microvessels. PLOS ONE 8:e71263. doi: 10.1371/journal.pone.0071263

Ortiz-Zapater, E., Peiró, S., Roda, O., Corominas, J. M., Aguilar, S., Ampurdanés, C., et al. (2007). Tissue plasminogen activator induces pancreatic cancer cell proliferation by a non-catalytic mechanism that requires extracellular signal-regulated kinase $1 / 2$ activation through epidermal growth factor receptor and annexin A2. Am. J. Pathol. 170, 1573-1584. doi: 10.2353/ajpath.2007.060850

Pang, P. T., Teng, H. K., Zaitsev, E., Woo, N. T., Sakata, K., Zhen, S., et al. (2004). Cleavage of proBDNF by tPA/plasmin is essential for long-term hippocampal plasticity. Science 306, 487-491. doi: 10.1126/science.1100135

Paoletti, P., Bellone, C., and Zhou, Q. (2013). NMDA receptor subunit diversity: impact on receptor properties, synaptic plasticity and disease. Nat. Rev. Neurosci. 14, 383-400. doi: 10.1038/nrn3504

Parcq, J., Bertrand, T., Montagne, A., Baron, A. F., Macrez, R., Billard, J. M., et al. (2012). Unveiling an exceptional zymogen: the single-chain form of tPA is a selective activator of NMDA receptor-dependent signaling and neurotoxicity. Cell Death. Differ. 19, 1983-1991. doi: 10.1038/cdd.2012.86

Park, L., Gallo, E. F., Anrather, J., Wang, G., Norris, E. H., Paul, J., et al. (2008). Key role of tissue plasminogen activator in neurovascular coupling. Proc. Natl. Acad. Sci. U.S.A. 105, 1073-1078. doi: 10.1073/pnas.0708823105

Pawlak, R., Nagai, N., Urano, T., Napiorkowska-Pawlak, D., Ihara, H., Takada, Y., et al. (2002). Rapid, specific and active site-catalyzed effect of tissue-plasminogen activator on hippocampus-dependent learning in mice. Neuroscience 113, 995-1001. doi: 10.1016/S0306-4522(02)00166-5

Pennica, D., Holmes, W. E., Kohr, W. J., Harkins, R. N., Vehar, G. A., Ward, C. A., et al. (1983). Cloning and expression of human tissue-type plasminogen activator cDNA in E. coli. Nature 301, 214-221. doi: 10.1038/ $301214 \mathrm{a} 0$ 
Petersen, L. C., Johannessen, M., Foster, D., Kumar, A., and Mulvihill, E. (1988). The effect of polymerised fibrin on the catalytic activities of onechain tissue-type plasminogen activator as revealed by an analogue resistant to plasmin cleavage. Biochim. Biophys. Acta 952, 245-254. doi: 10.1016/01674838(88)90123-9

Pineda, D., Ampurdanés, C., Medina, M. G., Serratosa, J., Tusell, J. M., Saura, J., et al. (2012). Tissue plasminogen activator induces microglial inflammation via a noncatalytic molecular mechanism involving activation of mitogen-activated protein kinases and Akt signaling pathways and AnnexinA2 and Galectin-1 receptors. Glia 60, 526-540. doi: 10.1002/glia.22284

Pohl, G., Källström, M., Bergsdorf, N., Wallén, P., and Jörnvall, H. (1984). Tissue plasminogen activator: peptide analyses confirm an indirectly derived amino acid sequence, identify the active site serine residue, establish glycosylation sites, and localize variant differences. Biochemistry 23, 3701-3707. doi: 10.1021/bi00311a020

Polavarapu, R., Gongora, M. C., Yi, H., Ranganthan, S., Lawrence, D. A., Strickland, D., et al. (2007). Tissue-type plasminogen activator - mediated shedding of astrocytic low-density lipoprotein receptor - related protein increases the permeability of the neurovascular unit. Blood 109, 3270-3278. doi: 10.1182/blood-2006-08-043125

Rånby, M., Bergsdorf, N., and Nilsson, T. (1982). Enzymatic properties of the oneand two-chain form of tissue plasminogen activator. Thromb. Res. 27, 175-183. doi: 10.1016/0049-3848(82)90197-9

Rathore, Y. S., Rehan, M., Pandey, K., and Ashish, S. G. (2012). First structural model of full-length human tissue-plasminogen activator: a SAXS databased modeling study. J. Phys. Chem. B. 116, 496-502. doi: 10.1021/ jp207243n

Reddrop, C., Moldrich, R. X., Beart, P. M., Farso, M., Liberatore, G. T., Howells, D. W., et al. (2005). Vampire bat salivary plasminogen activator (desmoteplase) inhibits tissue-type plasminogen activator-induced potentiation of excitotoxic injury. Stroke 36, 1241-1246. doi: 10.1161/01.STR.0000166050.84056.48

Rijken, D. C., Wijngaards, G., Jong, M. Z., and Welbergen, J. (1979). Purification and partial characterization of plasminogen activator from human uterine tissue. Biochim. Biophys. Acta 580, 140-153. doi: 10.1016/0005-2795(79) 90205-8

Rodríguez-González, R., Agulla, J., Pérez-Mato, M., Sobrino, T., and Castillo, J. (2011). Neuroprotective effect of neuroserpin in rat primary cortical cultures after oxygen and glucose deprivation and tPA. Neurochem. Int. 58, 337-343. doi: 10.1016/j.neuint.2010.12.006

Roussel, B. D., Macrez, R., Jullienne, A., Agin, V., Maubert, E., Dauphinot, L., et al. (2009). Age and albumin D site-binding protein control tissue plasminogen activator levels: neurotoxic impact. Brain 132, 2219-2230. doi: 10.1093/brain/awp162

Roussel, B. D., Mysiorek, C., Rouhiainen, A., Jullienne, A., Parcq, J., Hommet, Y., et al. (2011). HMGB-1 promotes fibrinolysis and reduces neurotoxicity mediated by tissue plasminogen activator. J. Cell Sci. 124, 2070-2076. doi: 10.1242 /jcs.084392

Samson, A. L., Nevin, S. T., Croucher, D., Niego, B., Daniel, P. B., Weiss, T. W., et al. (2008). Tissue-type plasminogen activator requires a co-receptor to enhance NMDA receptor function. J. Neurochem. 107, 1091-1101. doi: 10.1111/j.14714159.2008.05687.x

Shi, R., Weng, J., Zhao, L., Li, X. M., Gao, T. M., and Kong, J. (2012). Excessive autophagy contributes to neuron death in cerebral ischemia. CNS Neurosci. Ther. 18, 250-260. doi: 10.1111/j.1755-5949.2012.00295.x

Siao, C. J., and Tsirka, S. E. (2002). Tissue plasminogen activator mediates microglial activation via its finger domain through annexin II. J. Neurosci. 22, 3352-3358.

Siddiq, M. M., and Tsirka, S. E. (2004). Modulation of zinc toxicity by tissue plasminogen activator. Mol. Cell. Neurosci. 25, 162-171. doi: 10.1016/j.mcn.2003.10.007

Spellman, M. W., Basa, L. J., Leonard, C. K., Chakel, J. A., O’Connor, J. V., Wilson, S., et al. (1989). Carbohydrate structures of human tissue plasminogen activator expressed in Chinese hamster ovary cells. J. Biol. Chem. 264, 1410014111.

Sun, H. Y., Szlam, F., Levy, J. H., Csete, M. E., and Tanaka, K. A. (2009). Antifibrinolytic agents reduce tissue plasminogen activator-mediated neuronal toxicity in vitro. Acta Anaesthesiol. Scand. 53, 325-331. doi: 10.1111/j.13996576.2008.01858.x
Tate, K. M., Higgins, D. L., Holmes, W. E., Winkler, M. E., Heyneke, H. L., and Vehar, G. A. (1987). Functional role of proteolytic cleavage at arginine-275 of human tissue plasminogen activator as assessed by site-directed mutagenesis. Biochemistry 26, 338-343. doi: 10.4049/jimmunol.1100412

Terro, F., Esclaire, F., Yardin, C., and Hugon, J. (2000). N-methyl-D-aspartate receptor blockade enhances neuronal apoptosis induced by serum deprivation. Neurosci. Lett. 278, 149-152. doi: 10.1016/S0304-3940(99)00911-8

Thelwell, C., and Longstaff, C. (2007). The regulation by fibrinogen and fibrin of tissue plasminogen activator kinetics and inhibition by plasminogen activator inhibitor 1. J. Thromb. Haemost. 5, 804-811. doi: 10.1111/j.15387836.2007.02422.x

Tsirka, S. E., Bugge, T. H., Degen, J. L., and Strickland, S. (1997a). Neuronal death in the central nervous system demonstrates a non-fibrin substrate for plasmin. Proc. Natl. Acad. Sci. U.S.A. 94, 9779-9781. doi: 10.1073/pnas.94.18.9779

Tsirka, S. E., Rogove, A. D., Bugge, T. H., Degen, J. L., and Strickland, S. (1997b). An extracellular proteolytic cascade promotes neuronal degeneration in the mouse hippocampus. J. Neurosci. 17, 543-552.

Tsirka, S. E., Gualandris, A., Amaral, D. G., and Strickland, S. (1995). Excitotoxininduced neuronal degeneration and seizure are mediated by tissue plasminogen activator. Nature 377, 340-344. doi: 10.1038/377340a0

Tucker, H. M., Kihiko, M., Caldwell, J. N., Wright, S., Kawarabayashi, T., Price, D., et al. (2000). The plasmin system is induced by and degrades amyloid-beta aggregates. J. Neurosci. 20, 3937-3946.

Vandenberghe, W., Van Den Bosch, L., and Robberecht, W. (1998). Tissue-type plasminogen activator is not required for kainate-induced motoneuron death in vitro. Neuroreport 9, 2791-2796. doi: 10.1097/00001756-199808240-00020

Wallén, P., Bergsdorf, N., and Rånby, M. (1982). Purification and identification of two structural variants of porcine tissue plasminogen activator by affinity adsorption on fibrin. Biochim. Biophys. Acta 719, 318-328. doi: 10.1016/03044165(82)90105-2

Wang, X., Asahi, M., and Lo, E. H. (1999). Tissue type plasminogen activator amplifies hemoglobin-induced neurotoxicity in rat neuronal cultures. Neurosci. Lett. 274, 79-82. doi: 10.1016/S0304-3940(99)00682-5

Wang, Y. F., Tsirka, S. E., Strickland, S., Stieg, P. E., Soriano, S. G., and Lipton, S. A. (1998). Tissue plasminogen activator (tPA) increases neuronal damage after focal cerebral ischemia in wild-type and tPA-deficient mice. Nat. Med. 4, 228-231. doi: 10.1038/ng0598-56

Wiegler, K., Bonny, C., Coquoz, D., and Hirt, L. (2008). The JNK inhibitor XG-102 protects from ischemic damage with delayed intravenous administration also in the presence of recombinant tissue plasminogen activator. Cerebrovasc. Dis. 26, 360-366. doi: 10.1159/000151639

Wittwer, A. J., and Howard, S. C. (1990). Glycosylation at Asn-184 inhibits the conversion of single-chain to two-chain tissue-type plasminogen activator by plasmin. Biochemistry 29, 4175-4180. doi: 10.1021/bi00469a021

Wittwer, A. J., Howard, S. C., Carr, L. S., Harakas, N. K., Feder, J., Parekh, R. B., et al. (1989). Effects of $\mathrm{N}$-glycosylation on in vitro activity of Bowes melanoma and human colon fibroblast derived tissue plasminogen activator. Biochemistry 28, 7662-7669. doi: 10.1021/bi00445a022

Wu, F., Echeverry, R., Wu, J., An, J., Haile, W. B., Cooper, D. S., et al. (2013a). Tissue-type plasminogen activator protects neurons from excitotoxin-induced cell death via activation of the ERK1/2-CREB-ATF3 signaling pathway. Mol. Cell. Neurosci. 52, 9-19. doi: 10.1016/j.mcn.2012.10.001

Wu, F., Nicholson, A. D., Haile, W. B., Torre, E., An, J., Chen, C., et al. (2013b). Tissue-type plasminogen activator mediates neuronal detection and adaptation to metabolic stress. J. Cereb. Blood Flow Metab. 33, 1761-1769. doi: 10.1038/jcbfm.2013.124

Wu, F., Wu, J., Nicholson, A. D., Echeverry, R., Haile, W. B., Tong, F. C., et al. (2012). Tissue-type plasminogen activator regulates the neuronal uptake of glucose in the ischemic brain. J. Neurosci. 32, 9848-9858. doi: 10.1523/JNEUROSCI.1241-12.2012

Yi, J. S., Kim, Y. H., and Koh, J. Y. (2004). Infarct reduction in rats following intraventricular administration of either tissue plasminogen activator (tPA) or its non-protease mutant S478A-tPA. Exp. Neurol. 189, 354-360. doi: 10.1016/j.expneurol.2004.05.032

Yuan, H., Vance, K. M., Junge, C. E., Geballe, M. T., Snyder, J. P., Hepler, J. R., et al. (2009). The serine protease plasmin cleaves the amino-terminal domain of the NR2A subunit to relieve zinc inhibition of the N-methyl-D-aspartate receptors. J. Biol. Chem. 284, 12862-12873. doi: 10.1074/jbc.M805123200 
Zhang, Z., Zhang, L., Yepes, M., Jiang, Q., Li, Q., Arniego, P., et al. (2002). Adjuvant treatment with neuroserpin increases the therapeutic window for tissue-type plasminogen activator administration in a rat model of embolic stroke. Circulation 106, 740-745. doi: 10.1161/01.CIR.0000023942.10849.41

Conflict of Interest Statement: The authors declare that the research was conducted in the absence of any commercial or financial relationships that could be construed as a potential conflict of interest.
Copyright (c) 2015 Chevilley, Lesept, Lenoir, Ali, Parcq and Vivien. This is an open-access article distributed under the terms of the Creative Commons Attribution License (CC BY). The use, distribution or reproduction in other forums is permitted, provided the original author(s) or licensor are credited and that the original publication in this journal is cited, in accordance with accepted academic practice. No use, distribution or reproduction is permitted which does not comply with these terms. 